\title{
FEUERBACH, MARX, NIETZSCHE E FREUD: A CRÍTICA DA RELIGIÃO NO SÉCULO XIX
}

\author{
FEUERBACH, MARX, NIETZSCHE E FREUD: THE CRITIQUE OF RELIGION IN THE NINETEENTH \\ CENTURY
}

Fabiano veliq*

\begin{abstract}
RESUMO
Neste artigo procurar-se-á contextualizar o debate sobre a religião, expondo as ideias dos principais autores que influenciaram a crítica da religião no século XIX tais como Feuerbach, Marx, Nietzsche e Freud. Procurar-se-á mostrar que esses autores têm algo em comum que a filosofia da religião posterior busca superar. Todos esses filósofos lidam de uma forma ou de outra com a questão da "morte de Deus". Eles anunciam e confirmam esse fato cada um à sua maneira, mas com diálogos bastante possíveis entre eles. A começar com Feuerbach e culminando em Freud, Deus é banido enquanto realidade possível. Se Deus está banido, a religião que fala desse Deus deve também ser banida, e outra coisa deve ser colocada em seu lugar. Procurar-se-á, neste sentido, demonstrar como que cada autor lida com a questão da religião e com isso evidenciar como que tais críticas são cruciais para o desenvolvimento da filosofia da Religião no século XX.
\end{abstract}

PALAVRAS-CHAVE: Religião. Ateísmo. Vida. Ilusão.

\begin{abstract}
In this article we will try to contextualize the debate about religion, exposing the ideas of the main authors who influenced the critique of religion in the nineteenth century such as Feuerbach, Marx, Nietzsche and Freud. It will be tried to show that these authors have something in common that the philosophy of the later religion seeks to surpass. All these philosophers deal in one way or another with the question of the "death of God." They announce and confirm this fact each one in their own way, but with possible dialogues between them. Beginning with Feuerbach and culminating in Freud, God is banished as a possible reality. If God is banished, the religion that speaks of this God must also be banished and something else must be put in its place. We will try, in this sense, demonstrate how each author deals with the question of religion and with that put in evidence how that critics are crucials to development of philosophy of religion in twentieth century.
\end{abstract}

KEYWORDS: Religion, Atheism, Life, Illusion.

\footnotetext{
* Mestre em Filosofia da Religião pela FAJE e Doutor em Psicologia pela PUC Minas. Doutorando em filosofia pela UFMG. Professor do Departamento de Filosofia da PUC Minas. E-mail: veliqs@gmail.com.
} 


\section{INTRODUÇÃO}

A “morte de Deus" tematizada por Nietzsche e já evidenciada por esses filósofos anteriores a ele fará com que a teologia e a filosofia da religião, ao discutir a religião, lide com esse problema, e é a partir de uma reinterpretação da "morte de Deus" que esse ramo do conhecimento fará a crítica a esses filósofos. Em sua análise da questão, Rubem Alves, seguindo Buber, propõe que, em vez de morte, o que de fato aconteceu foi um eclipse de Deus (ALVES, 2007, p. 61). É preciso trazer Deus de volta, mas Ele não é mais o mesmo. Com essa postura, Alves se relaciona com uma corrente teológica de sua época, que é a "teologia da morte de Deus", com a qual ele teve mais contato a partir dos escritos do teólogo alemão Dietrich Bonhoeffer. A chamada“teologia da morte de Deus" coloca sob uma nova perspectiva a questão de Deus na contemporaneidade. A "morte de Deus" significa que a linguagem oferecida pelo teísmo entrou em colapso e teve como efeito o fim de uma visão de mundo. Como afirma Alves (2007, p. 60), “o que está em jogo é a constatação de que as estruturas de pensamento e de linguagem que o teísmo oferecia entraram em colapso. Chegou ao fim uma certa visão do universo". Deus passará a ser visto de outra forma na teologia, pois ela precisa lidar com essas críticas que aparecem advindas do final do século XIX. Se o discurso científico elimina Deus como possibilidade, na subjetividade humana ele se faz necessário. A religião, portanto, não tem o seu fim, mas adquire uma nova dimensão.

O presente artigo apresentará as ideias dos filósofos que influenciaram a crítica da religião no século XIX de modo a contextualizar o debate e apresentar de maneira sucinta por onde passam as ideias destes autores.

\section{A RELIGIÃO COMO OBJETIVAÇÃO EM FEUERBACH}

Ludwig Andreas Feuerbach foi um filósofo alemão que teve como seu principal objetivo analisar a religião de seu tempo o cristianismo. Ele mesmo afirma que "Deus foi meu primeiro pensamento; a razão, o segundo; o homem, o terceiro e último" (apud SOUZA, 1994, p. 19).

Por meio dessa colocação, podem-se perceber os principais períodos do pensamento feuerbachiano. Primeiramente, o filósofo se ocupa da reflexão sobre Deus como estudante de teologia em Heidelberg, onde mantém contato com o teólogo hegeliano Karl Daub. Tempos depois, ele se dirige a Berlin, onde é aluno de Hegel, etapa que corresponderia ao segundo momento de seu pensamento, a saber, a razão. No final de sua vida, afasta-se do 
hegelianismo e assume uma postura materialista, formulando uma filosofia da religião que se distanciará bastante da proposta de Hegel.

Em 1828, obtém o seu doutoramento com sua tese intitulada De ratione una, universali, infinita. De 1829 a 1832, segue sua carreira docente como professor auxiliar de história da filosofia, de lógica e de metafísica. Em virtude da publicação anônima de sua obra Pensamentos sobre morte e imortalidade, em 1830, em que ele vai de encontro à ideia de um Deus-Pessoa e nega a imortalidade pessoal, Feuerbach é impedido de assumir o posto de professor na universidade. Sua carreira docente universitária acaba de forma abrupta. Esse itinerário fez com que praticamente toda a filosofia feuerbachiana fosse construída de maneira particular: longe das universidades. Isso garantiu, por outro lado, uma maior liberdade ao filósofo.

De todas as obras de Feuerbach, a mais importante é A essência do cristianismo, em que fica clara a posição dele sobre a essência da religião, bem como a sua tentativa de reduzir esta à antropologia. Outra obra importante também é Preleções sobre a essência da religião, em que o debate sobre a religião será mantido, porém com maior ênfase histórica.

O método adotado por Feuerbach nessas duas obras citadas, para propiciar uma crítica à religião, se caracterizará pela redução da teologia à antropologia. Segundo o filósofo,

\footnotetext{
Esta minha doutrina é simplesmente: teologia é antropologia, ou seja, no objeto da religião a que chamamos théos em grego, Gott em alemão, expressa-se nada mais do que a essência do homem, ou: o deus do homem não é nada mais que a essência divinizada do homem. (FEUERBACH apud SOUZA, 1994, p. 33).
}

Conforme afirma Souza (1994 p. 32), “o princípio explicativo adotado por Feuerbach pode ser denominado de redução." O termo projeção, comumente usado para analisar a questão de Deus no pensamento desse filósofo, não seria adequado, uma vez que ele nunca o teria usado. A ideia de projeção teria sido introduzida por Hartmann, em sua obra História da metafísica, para caracterizar a teoria feuerbachiana sobre a teologia. A partir do processo de redução, Feuerbach fará a crítica à religião, tentando mostrar que, no final, a teologia não passa de antropologia.

Feuerbach, ao fazer a análise da religião, parte da diferença que existe entre os homens e os animais. Para ele, apenas os seres humanos fazem religião, pois não há nos animais algo que se assemelhe ao comportamento humano que gera a religião. Essa diferença poderia ser resumida pela palavra consciência. A consciência seria o que diferenciaria o homem do animal, sendo o fundamento para a religião, de acordo com o autor. Percebe-se que isso 
coloca a religião como algo totalmente humano, uma vez que ela se funda no aspecto que constitui a diferença essencial entre o homem e o animal: a consciência.

$\mathrm{Na}$ teoria feuerbachiana, são considerados dois tipos de consciência. Uma seria entendida em sentido amplo e a outra, em sentido estrito. A primeira seria própria aos animais e se resumiria à consciência de si apenas enquanto indivíduo; a segunda, em sentido estrito, seria própria do ser humano, que se vê enquanto indivíduo e enquanto gênero. Segundo Feuerbach (2002, p. 9-10), "consciência em sentido estrito só existe quando um ser tem como objeto o seu gênero, a sua essencialidade (...) Consciência em sentido estrito ou próprio e consciência do infinito é o mesmo."

Com essa diferenciação, o filósofo quer mostrar que a essência humana é o fundamento da religião, uma vez que esta se funda numa característica intrinsecamente humana. Além disso, ele também busca confirmar como a essência humana é o objeto da religião, pois, em sentido estrito, a consciência é consciência do infinito e, portanto, consciência de algo universal e não apenas individual.

Feuerbach (2002, p. 10-11) diz que

a religião em geral, enquanto idêntica à essência do homem, é idêntica à consciência de si do homem, à consciência que o homem tem de sua essência. Mas a religião é, numa expressão geral, consciência do infinito; portanto, não é e não pode ser outra coisa senão a consciência que o homem tem de sua essência, a saber, de uma essência não finita, limitada, mas infinita [...]. A consciência do infinito não é senão a consciência da infinitude da consciência. Ou melhor: só na consciência do infinito é que o ser consciente tem como objeto a infinitude da própria essência.

Assim ele relaciona o objeto da consciência ao objeto da religião, substituindo a essência divina pela humana e mostrando que a infinitude daquela deve-se à infinitude desta, uma vez que a religião não passa de consciência da infinitude da consciência.

Feuerbach afirma que cada um tem em si o seu próprio Deus. Dessa forma, quando alguém louva a magnificência de Deus, louva a magnificência da essência humana, pois toda admiração seria no fundo autoadmiração. O homem, ao falar de Deus, fala de si próprio, porém colocando todo o gênero humano como extensão sua.

A consciência de Deus é a consciência de si do homem, o conhecimento de Deus o conhecimento de si do homem. Pelo seu Deus conheces o homem e, vice-versa, pelo homem conheces o seu Deus; é a mesma coisa. [...] Deus é o interior revelado, o simesmo do homem expresso, a religião é o desvendamento festivo dos tesouros escondidos do homem, a confissão dos seus pensamentos mais íntimos, a proclamação pública dos seus segredos de amor. (FEUERBACH, 2002, p. 22-23). 
Para o filósofo, a falta da consciência de que Deus, na realidade, não passa da essência humana objetivada é o que funda a religião. O indivíduo religioso não sabe que sua prática é a exaltação de sua própria essência. A religião surge quando o homem separa Deus de si mesmo, quando o primeiro vê este último como Pessoa para além dos desejos humanos e passa a venerá-1O como se Dele dependessem todas as coisas. A religião, no final, é apenas a atitude do ser humano diante da sua própria essência, mas esta é tomada como algo exterior a si, como uma essência diferente, como a essência divina. Esta é a essência humana purificada e liberta das limitações do homem natural, por isso toda as determinações da essência divina são determinações humanas e nada além disso. Isso fica claro quando Feuerbach (2002 p. 41) diz que "a religião é a cisão do homem consigo: ele põe Deus face a si como um ser que lhe é oposto. Deus não é o que o homem é - o homem não é o que Deus é.”

Enquanto Deus é a soma de tudo o que é positivo, perfeito, todo-poderoso, o homem se torna a soma de tudo que é negativo, imperfeito, fraco e pecador. Tal diferenciação acaba por deixar o homem alienado de si, colocando tudo o que pode ser feito nas mãos de Deus. Este se torna, então, tudo, e o homem torna-se nada.

Nas Preleções sobre a essência da religião, Feuerbach afirma que há dois tipos de religião: as religiões da natureza, cujo Deus seria apenas a natureza vista como algo divinizado, e as religiões do espírito, cujo Deus seria apenas a essência do homem objetivada. Para ele o cristianismo se encontra nesse segundo tipo, e as religiões politeístas no primeiro tipo. No entanto, ambas se fundam na separação entre a essência do homem e a essência de Deus.

Segundo Feuerbach (1989, p. 151),

O sentimento que impele o homem à adoração de um objeto pressupõe que esse objeto não seja insensível a essa adoração, portanto que tenha sentimento, que tenha um coração humano sensível aos interesses humanos. [...] Mas o que transforma uma entidade natural num ser humano? A fantasia, a imaginação.

É a imaginação que cria os deuses dos homens. O filósofo considera que palavra deus não indica um ser, mas é um nome genérico dado a tudo que pareça divino ao homem à luz da fantasia. Por isso qualquer coisa pode ser objeto de adoração religiosa. Ele equipara Deus à adoração religiosa porque, para Feuerbach, não existe outra característica da divindade a não ser a adoração religiosa. "Um deus é o que é adorado. Mas um objeto só é adorado quando e enquanto for uma entidade, um objeto da fantasia ou da imaginação" (FEUERBACH, 1989, p. 151). 
Dessa forma, qualquer objeto pode ser adorado pelo homem como se fosse Deus, isto é, adorado pelo homem de maneira religiosa. Esse estágio é chamado, pelo filósofo, de feitichismo. Este surge quando são transformados em deuses, sem qualquer crítica ou distinção, todos os objetos e coisas possíveis, sejam artificiais ou naturais, produtos da natureza ou do homem. A razão disso é a fantasia. Em relação a isso, Feuerbach (1989 p. 152) considera que a imaginação do homem é tanto mais forte quanto mais ignorante o homem é. Por não conhecer o que uma coisa é, o indivíduo atribui a ela um valor maior do que o real. "Por isso, a causa ou a fonte teorética da religião e de seu objeto, Deus, é a fantasia, a imaginação."

Segundo Feuerbach (1989 p. 152), “esse poder da fé ou de Deus que não se prende a nenhuma lei natural é exatamente o poder da imaginação." O poder da fé é o poder da imaginação, da fantasia. A fé acredita em milagres, não se prende à natureza, ela é livre e ilimitada, crê que tudo é possível para Deus. Assim como a fé, a fantasia também é a certeza de coisas que não vemos. "A imaginação só se ocupa com coisas e seres que não estão mais ou ainda não estão ou simplesmente não estão presentes" (p. 152). Assim, se a fé é imaginação, e como Deus seria encontrado apenas mediante a fé, Deus é, portanto, fruto da imaginação humana. Como conclui Feuerbach, Deus é um ser imaginário, uma entidade da fantasia. A fantasia, por sua vez, é a forma, a essência ou o órgão da poesia. Logo, pode-se também dizer que a religião é poesia, e que Deus é um ser poético. E, segundo o filósofo, é nesse ponto que a crítica à religião deve residir.

Só combato a religião enquanto ela não é poesia, mas sim uma prosa vulgar. Com isto chegamos agora a uma restrição essencial da frase: religião é poesia. Sim, ela é, mas com a diferença da poesia, da arte em geral, que a arte não toma suas criações por coisas que não são, mas simplesmente por criações da arte; mas a religião considera suas entidades fictícias como entidades reais. (FEUERBACH, 1989, p. 154).

Essa é a diferença entre arte e religião. Ambas criam imagens, mas o homem se ilude na religião, conferindo realidade a uma forma de arte. Isso é assim porque a religião permite que suas imagens sejam úteis aos indivíduos, ajudando-os na dificuldade. No entanto, só o homem pode ajudar o homem. Somente ele pode ter sentimentos humanos diante das dificuldades humanas.

Para Feuerbach, a religião teria sua base no anseio de felicidade. Ele parte do pressuposto aristotélico de que todo homem quer ser feliz e, por isso, cria deuses, objetivando sua essência para além de si, satisfazendo assim seu desejo de felicidade. Segundo Feuerbach, 
Os deuses são os desejos do homem pensados como reais transformados em entidades reais. Um Deus é a ânsia de felicidade do homem satisfeita na fantasia. Se o homem não tivesse desejos, não teria religião nem deuses, apesar da fantasia e do sentimento. (FEUERBACH, 1989, p. 168).

Pode-se notar que a redução proposta por Feuerbach, em A essência do cristianismo, é retomada nas Preleções de uma forma mais contundente, e é nesse texto que ele deixa claro o seu objetivo:

Interessa-me acima de tudo, e sempre me interessou iluminar a obscura essência da religião com a luz da razão para que finalmente os homens parem de ser explorados, para que deixem de ser joguetes de todos aqueles poderes inimigos da humanidade que, como sempre, servem-se até hoje da nebulosidade da religião para a opressão do homem. Minha intenção era mostrar que os poderes diante dos quais o homem se curva e os quais teme na religião, diante dos quais ele não se intimida nem mesmo de praticar sangrentos sacrifícios humanos a fim de aplacá-los são apenas criações de sua própria afetividade servil e medrosa. Mostrar que um ser distinto dele próprio é sua própria essência, para que o homem, uma vez que é sempre dominado inconscientemente por ela, faça no futuro conscientemente sua própria essência, isto é, faça da essência humana, a lei, o fundamento, a meta e o critério de sua moral e de sua política. Exatamente esse intuito, ou seja, o conhecimento da religião para a promoção da liberdade humana, da autonomia, do amor, determinou também toda a extensão de minha abordagem histórica da religião. A meta de minhas obras assim como de minhas preleções é: tornar os homens de teólogos, antropólogos, de teófilos, filantropos, de candidatos do além, estudantes do aquém, de servos religiosos e políticos da monarquia e da aristocracia terrestre e celeste, cidadãos da terra, livres e conscientes. (FEUERBACH, 1989, p. 28).

Percebe-se que há um caráter social indicado no pensamento do filósofo, pois, para ele, a partir da crítica da religião, o ser humano poderia se libertar das amarras que o prendem e poderia novamente amar a terra e se desenvolver independente da coerção trazida pela religião. Uma vez que a religião tem um fim prático, isto é, trazer a natureza para a mão dos indivíduos, transformá-la em algo domável, manipulável pelo instinto de conservação deles, cabe ao homem desprender-se desse universo metafísico e entender a natureza como a base da religião.

A dependência que o homem tem da natureza é a base e o inicio da religião, mas a libertação dessa dependência tanto no sentido racional como no irracional é a libertação dessa dependência. A divindade da natureza é a base da religião, a divindade do homem é a meta da religião. (FEUERBACH, 1989, p. 174).

Feuerbach coloca-se, portanto, como arauto dessa meta da religião. Em seus escritos, ele procura mostrar que a religião nada mais é que a essência do homem divinizada. Assim, o que deve receber a primazia é o homem e não Deus. No final das Preleções, ele deixa claro sua esperança ao dizer que 
um dia os homens conhecerão a arte de ser morais e felizes sem um Deus. Só então serão verdadeiramente morais e felizes, quando não tiverem mais nenhum Deus e não necessitarem mais de nenhuma religião; porque só enquanto uma arte ainda incompleta, que ainda está de fraldas, necessita ela de proteção religiosa. (FEUERBACH, 1989, p. 179).

Para Feuerbach, portanto, o homem, à medida que conhecesse sua essência, afastar-seia das sombras da religião e caminharia livre rumo a sua felicidade. Se ainda não o fez, é porque ainda não tomou consciência dos fatos, e ainda precisa da religião para ampará-lo diante do mundo.

\section{A CRÍTICA DE MARX À RELIGIÃo}

Karl Marx, sem dúvida, é um dos grandes filósofos do século XIX. Sua filosofia até hoje é alvo de estudos não apenas no meio filosófico, mas também no meio econômico e político.

Karl Marx nasce em 5 de maio de 1818 em Tréveros, importante cidade da Prússia, país que exercia um forte papel na cultura da região como ponto de encontro do liberalismo revolucionário vindo da França e do conservadorismo do antigo regime, liderado pela Prússia. Nesse país, na época, segundo afirma Zilles (1991, p 120), a filosofia de Hegel tornara-se uma espécie de ideologia oficial.

Em 1836 Marx matricula-se na universidade de Berlim, capital da Prússia, e lá tem contato com o que, na história da filosofia, é conhecido como esquerda hegeliana. Começa a participar dos grupos de discussões sobre o pensamento de Hegel. Em 1841 ele defende sua tese de doutorado sobre o materialismo de Epicuro e Demócrito.

No ano de 1843 muda-se para Paris e lá conhece as ideias revolucionárias do socialismo de Fourier, de Owen e de Saint-Simon. Em Paris inicia sua amizade com Friedrich Engels e lá também desponta o seu interesse pela miséria do proletariado industrial.

Em 1845 passa a residir em Bruxelas, onde escreve com Engels algumas obras, tais como Ideologia alemã (1845), A miséria da filosofia (1847) e Manifesto comunista (1848). Expulso da Bélgica, volta à Alemanha, de onde, após a revolução de 1848, foi expulso, indo viver em Londres, tendo ali residido até o fim de sua vida. Foi nesta cidade que Marx publicou sua maior obra, $O$ capital, em 1867, na qual faz uma crítica à sociedade de sua época e mostra as relações que regem o sistema capitalista.

Como dito acima, Marx desde muito cedo tem contato com a filosofia hegeliana e é influenciado por ela, assim como pela esquerda hegeliana, principalmente por Feuerbach, 
assumindo em grande parte a crítica à religião deste filósofo. No entanto, Marx acusa veementemente a filosofia hegeliana de ser muito abstrata e de não se vincular a uma prática efetiva no mundo, como também critica a filosofia de Feuerbach por atribuir ao homem uma essência a-histórica. Se por um lado Marx aceita a crítica feuerbachiana da religião ao colocála como produção humana, por outro, ele rejeita uma essência humana que não seja determinada socialmente.

Marx parte do princípio de que não é a consciência que determina a sociedade, mas é esta que determina aquela. Segundo ele, "o homem não é um ser abstrato, agachado fora do mundo. O homem é o mundo do homem, o estado, a sociedade" (MARX, ENGELS, 2008, p. 5). Portanto, ao se falar sobre o homem, deve-se falar sobre o mundo do homem. O fenômeno religioso deve ser compreendido, portanto, dentro dessa nova perspectiva, não mais como objetivação de uma essência, como propõe Feuerbach, mas como produção social humana; "este estado, esta sociedade, produzem a religião, uma consciência invertida, porque eles são um mundo invertido" (MARX, ENGELS, 2008, p. 5).

Sendo uma consciência invertida do mundo, a religião é considerada basicamente falsa, pois nela só encontramos ilusão, não sendo necessário um processo hermenêutico de interpretação dela, já que ela deve ser superada. Nota-se que a interpretação feuerbachiana de religião enquanto objetivação de uma essência humana também é abandonada, e adquire em Marx o status de uma nova forma de mistificação. Se não há essência humana, o discurso sobre a religião enquanto objetivação dessa essência não passa de mera ilusão; "a religião é a realização, na fantasia, da essência humana, porque a essência humana não tem realidade alguma" (MARX, ENGELS, 2008, p. 5).

Se a religião é apenas expressão de um mundo invertido, ela não contém nenhuma verdade a ser recuperada. Ela não fala acerca de uma realidade a ser recuperada porque ela nada mais é que o resultado de um mundo a ser aniquilado.

Podemos notar que Marx preserva a relação entre religião e "expressão" humana. No entanto, para ele, aquela expressa não o homem, mas a situação do homem sob as condições de repressão. Ela é o suspiro das criaturas oprimidas, e, portanto, o discurso religioso não é sobre a "essência humana", mas sim sobre as correntes que aprisionam essas criaturas. O que se encontra em tal discurso não é o ser humano, mas as forças que o escravizam e o fazem gritar por religião. 
de um mundo sem coração, da mesma forma como ela é o espírito de uma situação sem espírito. Ela é ópio do povo. (MARX; ENGELS, 2008, p. 6).

Acontece no discurso religioso uma inversão, pois as correntes que limitam o indivíduo são cobertas por flores, e a dor real é esquecida pelo ópio. O homem, em vez de tentar se livrar das amarras religiosas que o escravizam, transforma tais correntes em canções de amor. Nota-se que, em Marx, não existe nenhum trânsito epistemológico da religião para a realidade. Aquela é inevitavelmente falsidade porque a sua função social é ser ópio. Isso permite defini-la funcionalmente como o discurso que reconcilia o homem com o mundo que o oprime.

Esse filósofo, portanto, reconhece a religião apenas como um sintoma de uma enfermidade social. Ela não contém nenhuma significação epistemológica, é apenas efeito de uma causa diversa de si mesma. Por isso, o autor passa a investigar qual seria a causa geradora da religião. Em vez de uma hermenêutica do discurso religioso, ele propõe uma crítica, a qual seria necessária para que a felicidade ilusória do povo possa ser substituída pela felicidade autêntica. "A abolição da religião como a felicidade ilusória do povo é exigida para a sua verdadeira felicidade. A exigência de que se abandonem as ilusões sobre as suas condições é a exigência para que se abandonem as condições que necessitam de ilusões" (MARX; ENGELS, 2008, p. 6).

A crítica da religião nos leva, portanto, para além dela. Tal reflexão não pretende recuperar a verdade do discurso religioso, como propõe Feuerbach, mas mostrar como ele é mero efeito de uma situação. Na realidade, a "felicidade ilusória" deve ser destruída para que, compreendendo a causa de sua infelicidade, o homem possa aboli-la e ser livre novamente. Por isso a crítica da religião somente tem sentido quando se abre para a crítica da sociedade geradora da necessidade da religião.

\footnotetext{
A crítica arrancou as flores imaginárias da corrente não para que o homem viva acorrentado sem fantasias ou consolo, mas para que ele quebre a corrente e colha a flor viva. A crítica da religião desilude o homem, a fim de fazê-lo pensar e agir e moldar a sua realidade como alguém que, sem ilusões, voltou à razão: agora ele gira em torno de si mesmo, o seu sol verdadeiro. A religião é nada mais que o sol ilusório que gira em torno do homem, na medida em que ele não gira em torno de si mesmo. (MARX; ENGELS, 2008, p. 6).
}

Percebe-se em Marx novamente uma superação da crítica religiosa de Feuerbach, pois não é mais somente uma crítica da consciência, mas sim da política, um meio para a crítica da sociedade. A alienação religiosa é vista como uma alienação de segunda ordem. A ilusão só existe porque há situações que exigem ilusões. Logo, Marx busca mostrar que a alienação 
religiosa nada mais é que a expressão ideal de uma alienação material. O que deve ser feito então não é alterar a expressão ideal, mas sim alterar as condições materiais que geram a expressão religiosa. Como Marx afirma na XI tese sobre Feuerbach, a questão não é reinterpretar o mundo, mas transformá-lo. Dessa forma, deixa a hermenêutica crítica e penetra na política. Por isso, em Marx, a crítica da religião é transformada em crítica social e política. Como a religião é apenas um efeito da infraestrutura socioeconômica, o que deve ser refeito é a infraestrutura.

A crítica de Marx à religião desemboca assim na crítica à sociedade capitalista. Isso constitui uma parte importante do pensamento de Marx que, por isso, deve ser levada em consideração no debate sobre a filosofia da religião.

Marx supera a crítica de Feuerbach, uma vez que coloca a religião não mais como mera objetivação de uma essência, mas como epifenômeno da estrutura socioeconômica. Nesse sentido, a crítica da religião transforma-se em crítica política; "a crítica dos céus se transforma em crítica da terra, a crítica da religião se transforma em crítica do direito e a crítica da teologia se transforma em crítica da política" (MARX; ENGELS, 2008, p. 6).

Podemos notar que a crítica feuerbachiana e a crítica de Marx à religião visam libertar o homem das correntes que a religião constrói para ele. Nesse sentido, a crítica desses autores procura dar ao homem as ferramentas para que ele se liberte da opressão religiosa e possa se constituir como homem livre. Percebe-se que Marx, assim como Feuerbach, vê a religião como algo a ser superado para que o homem conquiste a sua verdadeira liberdade.

\section{A RELIGIÃO COMO NEGAÇÃO DA VIDA EM NIETZSCHE}

Friedrich Nietzsche é um dos filósofos importantes do século XIX. Suas discussões sobre a religião e sobre Deus foram marcantes para a filosofia posterior e têm sido dignas de vários estudos até hoje.

Nietzsche nasceu em 15 de outubro de 1844 em Rocken, cidade da Prússia. Filho de pastor luterano, em sua mocidade pensa em seguir a profissão de seu pai. Com a morte deste, quando tinha apenas 5 anos de idade, é obrigado a mudar com sua mãe para Naumburgo. Em 1854 entra para o ginásio e quatro anos depois recebe uma bolsa para estudar em um internato em Pforta.

No ano de 1864, muda-se para Bonn a fim de estudar filologia clássica. Chegando lá, estuda primeiramente filosofia e teologia, tendo como professor Friedrich Ritschl, com o qual posteriormente se transfere para a Universidade de Leipzig. Já nessa cidade, toma contato 
com a obra de Schopenhauer e a partir de então se decide pelo ateísmo, abandonando definitivamente o cristianismo. Em 1869 Nietzsche torna-se professor de filologia clássica na Universidade de Basileia (Suíça). Alí, faz amizade com o músico Richard Wagner. Em 1879 pede demissão da Universidade de Basileia por motivo de saúde. Morre em 25 de agosto de 1900, vitimado por pneumonia e atormentado pela loucura.

O pensamento de Nietzsche é expresso em diversas temáticas, tais como: o eterno retorno do mesmo, o super-homem, a vontade de poder, a "morte de Deus", o niilismo. Todas essas temáticas indicam o esforço de revelar o sentido da existência do homem após a morte do deus da metafísica. Nietzsche escreve a maior parte de sua obra sob a forma de aforismos e talvez por isso uma sistematização de seu pensamento seja algo complicado. Nesse sentido, este trabalho atém-se apenas à crítica à religião feita pelo filósofo.

Como atesta Kaufmann (1974, p. 96), não devemos ignorar a conjuntura histórica da época em que Nietzsche entra no cenário filosófico. As filosofias especulativas de Schelling, Hegel e Schopenhauer, bem como a doutrina de Darwin sobre a evolução, tinham conquistado o mundo. Ao mesmo tempo, o exército prussiano estabeleceu a supremacia política no continente europeu, a ciência e a tecnologia estavam avançando aceleradamente e uma onda de otimismo tomava a Europa na época. Mas Nietzsche caracteriza essa fase europeia como niilista. Todo o conforto dessa geração, trazido por avanços tecnológicos, escondia um fato que os homens comuns não percebiam e que Nietzsche expôs de forma bem clara: o fato de que Deus está morto. No seu livro A gaia ciência, Nietzsche conta a parábola do louco para ilustrar a sociedade de sua época. Segundo ele,

Nunca ouviram falar do louco que acendia uma lanterna em pleno dia e desatava a correr pela praça pública gritando sem cessar: "Procuro Deus! Procuro Deus!" Mas como havia ali muitos daqueles que não acreditam em Deus, o seu grito provocou grande riso. "Ter-se-á perdido como uma criança" dizia um. "Estará escondido?" Terá medo de nós ? Terá embarcado? Terá emigrado?” Assim gritavam e riam todos ao mesmo tempo. O louco saltou no meio deles e trespassou-os com o olhar. "Para onde foi Deus?" Exclamou, é o que lhes vou dizer. Matamo-lo... vocês e eu! Somos nós, nós todos, que somos seus assassinos! Mas como fizemos isso? Como conseguimos isso? Como conseguimos esvaziar o mar? Quem nos deu uma esponja para apagar o horizonte inteiro? Que fizemos quando desprendemos a corrente que ligava esta terra ao sol? Para onde vai ela agora? Para onde vamos nós próprios? Longe de todos os sóis? Não estaremos incessantemente a cair? Para adiante, para trás, para o lado, para todos os lados? Haverá ainda um acima, um abaixo? Não estaremos errando através de um vazio infinito? Não sentiremos na face o sopro do vazio? Não fará mais frio? Não aparecem sempre noites? Não será preciso acender os candeeiros logo de manhã? Não ouvimos ainda nada do barulho que fazem os coveiros que enterram Deus? Ainda não sentimos nada da decomposição divina... ? Os deuses também se decompõem! Deus morreu! Deus continua morto! E fomos nós que o matamos! Como haveremos de nos consolar, nós, assassinos entre os assassinos! O que o mundo possui de mais sagrado e de mais poderoso até hoje sangrou sob o nosso punhal. Quem nos há de limpar desde sangue? Que água nos 
poderá lavar? Que expiações, que jogo sagrado seremos forçados a inventar? A grandeza deste ato é demasiado grande para nós. Não será preciso que nós próprios nos tornemos deuses para, simplesmente, parecermos dignos dela? Nunca houve ação mais grandiosa e, quaisquer que sejam, aqueles que poderão nascer depois de nós pertencerão, por causa dela, a uma história mais elevada do que, até aqui, nunca o foi qualquer história. (NIETZSCHE, 2004, p. 116).

Nietzsche se considera esse louco que grita na praça. Ter perdido Deus significa loucura, e quando os homens descobrirem que perderam Deus, a loucura se instaurará sobre eles. Os indivíduos destruíram a própria fé deles em Deus e com a morte deste vão-se embora a dignidade, os valores e os referenciais humanos. Tudo precisaria ser recriado. A "morte de Deus" será então a condição para a entrada do homem em uma nova história, superior à que viveu até agora. A "morte de Deus" garante a vitória do homem, que passará a ser responsável por criar seus próprios valores sem necessitar da tutela de alguém.

No entanto, Kaufmann chama a atenção para o fato de que, embora a existência de Deus possa diminuir o valor do homem, a morte Dele, ao mesmo tempo, deixa o ser humano com uma completa falta de sentido para a sua vida. Os homens que mataram Deus precisam agora lidar com o nada que fica em seu lugar. Essa morte então abre ao ser humano um novo horizonte, mas também o coloca diante do nada. Ele agora é o responsável por criar um novo mundo. Um mundo sem Deus, o que possibilita o surgimento do super-homem.

No entanto, Nietzsche constata que, interessantemente, os homens comuns não perceberam a "morte de Deus". Em A gaia ciência, o filósofo continua a descrever o louco que anda na praça:

[...] o insensato calou-se depois de pronunciadas estas palavras e voltou a olhar para os seus ouvintes: também eles se calavam, como ele, e o fitavam com espanto. Finalmente atirou a lanterna ao chão, de tal modo que se partiu e apagou. "Chego cedo demais", disse ele então "o meu tempo ainda não chegou. Esse acontecimento enorme está ainda a caminho, caminha e ainda não chegou ao ouvido dos homens. O relâmpago e o raio precisam de tempo, a luz dos astros precisa de tempo, as ações precisam de tempo, mesmo quando foram efetuadas, para serem vistas e entendidas. Esta ação ainda lhes está mais distante do que as mais distantes constelações; e foram eles contudo que a fizeram. Conta-se ainda que este louco entrou nesse mesmo dia em diversas igrejas e entoou o seu réquiem aeternam deo. Expulso e interrogado teria respondido inalteravelmente a mesma coisa " $\mathrm{O}$ que são estas igrejas mais do que túmulos e momentos fúnebres de Deus? (NIETZSCHE, 2004, p. 116).

Nesse texto, Nietzsche deixa bem claro que os homens assassinos de Deus não se deram conta do que fizeram. Continuam a agir como se Ele estivesse vivo, daí o porquê de continuarem entoando os hinos, indo às igrejas - meros túmulos de Deus, - fazendo as suas orações. 
Esses indivíduos encontram-se na primeira fase do processo de transformação ilustrado de forma maravilhosa no primeiro discurso sobre as três metamorfoses do espírito, em que Nietzsche apresenta a passagem do homem comum ao super-homem. Na parábola de Zaratustra, o ser humano passaria por três transformações. Primeiramente ele seria como o camelo, aquele que se inclina diante da hegemonia de Deus. Esse é o homem preso ao tu deves, submisso. No deserto ele se transformaria em leão, isto é, aquele que luta contra Deus e contra uma moral objetiva. O leão se opõe ao tu deves, passa a ser o eu quero. Num último momento, o homem libertar-se-ia, negando a Deus e a todos os valores que acompanham este nome. Isso o transformaria em criança e lhe conferiria a liberdade criadora.

Nessa parábola, Nietzsche ilustra o indivíduo que liberta a si mesmo e possibilita o nascimento do super-homem. No pensamento nietzscheano, a constatação de que Deus está morto faz com que tudo seja reavaliado, passando a Terra a ocupar o lugar Dele. O físico ocupa o lugar do metafísico. O corpo ocupa o lugar da razão abstrata. A "morte de Deus" evidencia, portanto, a grandeza humana. Essa grandeza atinge sua melhor expressão no superhomem nietzscheano. Ele será aquele que transvalorizará todos os valores de forma a exaltar a vida. Viver se transforma em inventar valores, através duma liberdade criadora para gerar um novo mundo que exalte a vida.

O super-homem terá, no entanto, que lidar com a consequência direta da "morte de Deus" que é o niilismo. Segundo Zilles (1991, p. 174), "Nietzsche via sua época como o fim da metafísica, da "morte de Deus" e do ateísmo. Tudo isso ele designa com o termo niilismo." No entanto, o niilismo para Nietzsche pode adquirir duas formas: o do forte e o do fraco. $\mathrm{O}$ niilismo do forte é ativo, é aquele que faz crescer a vontade de potência, que quer criar, enquanto o niilismo do fraco é passivo, decorrente da falta de força de construir um mundo que não dependa de uma metafísica; é o niilismo do cansaço, da decadência. A força criadora de sentido é abandonada e substituída por uma atitude de resignação diante da vida. Essa atitude do niilismo do fraco, na filosofia nietzschiana, é observada na religião. Esta se caracteriza como uma atitude de resignação diante da vida, uma negação da ação criadora do homem frente ao mundo, um colocar-se do homem sob a tutela de algo para além dele. A religião, portanto, evidencia a decadência humana, a partir do momento em que o indivíduo abandona a vontade de criar e se põe à mercê de um Deus.

O super-homem nietzschiano concretizará a vitória do homem sobre o niilismo. Para nascer o novo, é preciso que o velho morra. Os valores tradicionais precisam ser destruídos, e por isso o niilismo é uma passagem obrigatória. A transvaloração dos valores é realizada através da criação de novos valores, mas agora esses novos valores não terão mais o caráter 
dos antigos, não serão mais metafísicos, serão valores que exaltam a vida, a natureza. De acordo com Nietzsche, a vida deveria ser o valor supremo. O cristianismo nada mais fazia que destruir a vida e, por isso, deve ser negado.

Em $O$ anticristo, o filósofo afirma que

o cristianismo defendeu tudo quanto é fraco, baixo, pálido, fez um ideal da oposição aos instintos de conservação da vida potente, até corrompeu a razão das naturezas intelectualmente poderosas, ensinando que os valores superiores da intelectualidade não passam de pecados, extravios e tentações. (NIETZSCHE, 2007, p. 12).

A moral deverá ser naturalizada, e para isso será necessária a aceitação do mundo e da natureza como realidade última para o ser humano. O cristianismo deverá ser abandonado, assim como toda religião, toda metafísica. Essa proposta é uma negação de tudo que é fraco e uma exaltação do que é forte.

Visto isso, fica claro o porquê de uma crítica tão ferrenha ao cristianismo. Afinal, para Nietzsche, o cristianismo é uma tentativa singular de negar o mundo, pois em sua origem já há indícios de não passar de mera ficção. Segundo ele mesmo afirma na obra $O$ anticristo (2007, p. 45), "no fundo só houve um cristão e este morreu na cruz". A transformação posterior do cristianismo é fruto da obra de Paulo, que falsificou os ensinamentos de Cristo ao tentar sistematizar a felicidade proclamada por Jesus. Segundo afirmação de Nietzsche,

\footnotetext{
À boa-nova sucede imediatamente a pior de todas, a de Paulo. Em Paulo encarna-se o tipo oposto da boa-nova, o gênio do ódio, o visionário no ódio, na lógica inexorável do ódio [...] Que Paulo, cuja pátria era o centro do racionalismo estoico, possa ser considerado de boa-fé quando cria uma alucinação como prova da sobrevivência do redentor, ou mesmo só dar-lhe um voto de confiança quando conta que ele teve esta alucinação, isto seria uma verdadeira tolice da parte de um psicólogo; Paulo queria o fim, portanto queria também os meios... O que ele mesmo não acreditava, acreditaram-no os idiotas aos quais se dirigia sua doutrina. [...] A invenção de Paulo, seu meio de estabelecer a tirania sacerdotal, de formar rebanhos, a crença na imortalidade - Isto é a doutrina do julgamento. (NIETZSCHE, 2007, p. 49).
}

A leitura dos Evangelhos feita por Nietzsche lhe permite afirmar que o reino de Deus pregado por Jesus está no coração dos homens e não em um lugar metafísico, como foi afirmado por Paulo e seguido pelo cristianismo histórico. Ao considerar o reino de Deus como algo metafísico que deve ser alcançado por meio da mortificação da vida terrena, o cristianismo nega a vida e passa a vê-la como algo de valor inferior. Esse deslocamento da vida em direção ao além, para Nietzsche, nada mais faz do que colocar o homem em função 
de um outro mundo. Mundo este que é apenas criação humana para se livrar do nada. Como dito em Assim falou Zaratustra,

\begin{abstract}
A fadiga, que de um salto quer atingir o extremo, uma fadiga pobre e ignorante, que não quer ao menos um maior querer; foi ela que criou todos os deuses e todos os além-mundos. [...] Queriam fugir da miséria, e as estrelas estavam demasiado longe para eles. Então suspiraram: Oh se houvesse caminhos celestes para alcançar outra vida e outra felicidade! E inventaram os seus artifícios e as suas beberagens sangrentas. (NIETZSCHE, 2004, p. 40).
\end{abstract}

A afirmação do além-mundo evidencia o desprezo da vida e do corpo, o qual é chamado por Nietzsche de grande razão. Segundo ele,

O corpo é uma razão em ponto grande, uma multiplicidade com um só sentido, uma guerra, uma paz, um rebanho e um pastor. Instrumento do teu corpo é também a tua pequena razão a que chamas espírito: um pequeno instrumento e um brinquedo da tua grande razão. (NIETZSCHE, 2004, p. 41).

Nietzsche, ao fazer sua crítica da religião, pretende uma volta ao corpo enquanto a mais pura dimensão do humano. Para o filósofo, o cristianismo fez com que o homem esquecesse a primazia do corpo, e até mesmo incentivou que este fosse desprezado em prol da próxima vida em outra realidade. Tal situação será vista como mais um sintoma da decadência do cristianismo.

Percebe-se que a proposta nietzschiana coloca-se de forma bastante enfática contra o cristianismo e contra a metafísica. A religião, ao se pautar pela metafísica, acaba por negar a vida, e por isso deve ser negada para que a vida seja afirmada.

Nota-se aqui também a semelhança entre as ideias de Nietzsche e as de Feuerbach e de Marx em relação à religião, uma vez que todos defendem o ateísmo como forma de libertação do indivíduo. A religião, em todos os autores vistos até o momento, é algo que deve ser superado para que o homem se realize. Esse descrédito será em grande medida corroborado por Freud. Dessa forma, cabe agora analisar o pensamento desse último a respeito da religião, como uma espécie de corolário da via ateia inaugurada por Feuerbach.

\title{
A RELIGIÃO COMO REMÉDIO AO DESAMPARO EM FREUD.
}

Sigmund Freud nasceu em Freiberg, na Moravia, em 1856, numa família judaica ortodoxa e foi educado nesse tipo de cultura. Aos treze anos de idade, mudou-se com a família para Viena, onde passou a maior parte de sua vida. 
Estudou medicina e se dedicou muito à neurologia. Devido a esse contato com essa área da medicina, começou a estudar as neuroses. A partir de 1885, tornou-se docente privado de neuropatologia na Universidade de Viena. Da fisiologia passou à psicologia, área à qual se dedicou muito tempo e que o iniciou na psicanálise. Morreu em 23 de setembro de 1939, em Londres, deixando várias obras escritas e um vasto campo de conhecimento a ser explorado tanto por psicólogos quanto por psicanalistas e filósofos.

A religião é um dos temas abordados por Freud a partir de seu estudo das neuroses por ele observadas durante as sessões de análise em seu consultório. Ele escreveu vários textos tentando mostrar a natureza do fenômeno religioso, analisando o significado dos ritos e do comportamento religioso.

Como afirmam Rocha e Maciel, o trabalho interpretativo de Freud utiliza dois discursos inteiramente diferentes: um inspirado na ideologia iluminista e outro influenciado por um contexto mais amplo, como a interpretação da cultura e a compreensão psicanalítica do fenômeno religioso.

Freud utiliza dois discursos inteiramente diferentes: um inspirado na ideologia iluminista, que teve seu apogeu no século XVIII [...] Em virtude deste paradigma, as ciências da natureza [Naturwissenschaften] tornavam-se o modelo da verdadeira ciência. [...] Muito diferente é o discurso de Freud sobre a religião quando quem fala não é mais o Freud iluminista, mas aquele que Paul Ricouer chamou de Mestre da Suspeita. Este mestre procura desmascarar, também, na esfera do religioso, as formas de alienação, que nos impossibilitam a descoberta de nossa verdadeira condição humana. Se o discurso cientificista marcou o Freud pesquisador, o discurso analítico, no contexto mais amplo da interpretação freudiana da cultura, foi influenciado pela visão que tinha Freud do homem e pela sua compreensão psicanalítica do fenômeno religioso. (ROCHA; MACIEL, 2008, p. 729).

O discurso de Freud, portanto, é atravessado por duas vias distintas, mas que ao mesmo tempo convergem na análise freudiana da religião. Compreendendo esse entrelaçamento, fica mais clara a reflexão freudiana sobre religião, e isso impede que se atribua a ela apenas a ideia de religião como ilusão.

Carlos Roberto Drawin, em sua tese de doutorado intitulada Paradoxo da finitude: sobre o sentido onto-antropológico da psicanálise freudiana (2005), resume de forma bem clara os postulados epistemológicos e ontológicos sobre os quais o espírito cientificista se fundamenta no período em que Freud iniciava suas pesquisas psicanalíticas. Entre os postulados epistemológicos, Drawin destaca primeiramente o critério empírico-analítico, segundo o qual todo conhecimento orgina-se da experiência sensível e é por ela justificado, ao invés de partir de axiomas. Depois, o autor fala do monismo epistemológico, que afirma que apenas as ciências da natureza (Naturwissenschaften) merecem o nome de ciência, e do 
modelo fisicalista, para o qual a física é a ciência que melhor realiza o critério empíricoanalítico.

Entre os postulados ontológicos do cientificismo Drawin ressalta primeiramente o reducionismo fundacionista, em que considera que os fenômenos mais complexos devam ser reduzidos a fenômenos mais simples. Posteriormente, apresenta o monismo ontológico, o qual afirmaria que toda a realidade possui apenas um nível de realidade e varia de acordo com as correntes filosóficas, constituindo-se no espírito para o idealismo, na natureza para o naturalismo e na matéria para o materialismo. Os fenômenos físicos são mais reais e possuem maior densidade ontológica. E finalmente apresenta o modelo determinista, o qual postula que a ciência explica as experiências através do conhecimento dos processos causais. Na ciência, portanto, não haveria lugar para o acaso, e com a descoberta do inconsciente a crença nesse modelo determinista revigorou-se.

Em relação ao discurso religioso, Freud sempre se mostra influenciado tanto pela via iluminista quanto pela via da suspeita, e é justamente nessa oposição que se encontra a originalidade do pensamento de Freud sobre a religião. Como atestam Rocha e Maciel (2008, p. 730),

\footnotetext{
Enquanto pensador iluminista, ele sempre professou seu ateísmo radical e mais de uma vez afirmou sua descrença completa nos valores religiosos, todavia, o interesse pelo estudo da religião e, sobretudo pelo estudo das motivações psíquicas que estão na base das opções religiosas marcou toda a sua obra.
}

Freud inicia seus estudos sobre a religião com a publicação do texto Atos obsessivos $e$ prática religiosa, em 1907. Nesse texto chama a atenção para a analogia existente entre as cerimônias religiosas e os atos praticados pelas pessoas obsessivas. Segundo ele, na dinâmica psíquica do neurótico obsessivo, um recalque insatisfatório ocasiona um elevado grau de angústia. Para se livrar de tal sentimento, o doente lança mãos de defesas secundárias, dentre as quais estão os rituais obsessivos. O mesmo ocorre no homem religioso: a mesma "fuga" para uma defesa secundária se instala na tentativa de realizar o desejo recalcado. Como esse recalque não é capaz de suprimir a angústia, o homem religioso lança mão de cerimônias e práticas religiosas a fim de conseguir isso.

Segundo Rocha e Maciel (2008, p. 732), o religioso enfrenta um grande conflito, isto é, “obedecer às pulsões e desobedecer à lei ou obedecer à lei e abrir mão das pulsões. Sendo assim, os rituais assumem uma função protetora diante do conflito”. Freud (1907/1976, p. 111) 
considera que "os atos cerimoniais obsessivos surgem, em parte, como proteção contra o mal esperado".

Ao identificar o religioso com o obsessivo, Freud reflete sobre a questão religiosa do ponto de vista da psicanálise. Dessa forma, o que resta para ambos, o religioso e o obsessivo, é simplesmente procurar tratar-se desse mal e tentar viver uma vida que se pautaria pela via racional.

Já no final de sua vida, Freud escreve um livro intitulado $O$ futuro de uma ilusão, que é sem dúvida o texto mais lido quando se pretende entender a religião no pensamento desse autor. Nesse brilhante texto, a razão impera sobre o homem e as produções humanas devem ser submetidas ao tribunal por ela governado, inclusive a religião. Freud (1927/1976, p. 40) afirma que "acima da razão não há tribunal a que apelar. Se a verdade das doutrinas religiosas depende de uma experiência interior que dá testemunho dessa verdade, o que se deve fazer com as muitas pessoas que não dispõem dessa rara experiência?"

Religião e ciência não se misturam, ou se adota o paradigma científico ou o paradigma religioso. As funções da religião apontadas por Freud, tais como dar sentido à vida, controlar os impulsos e recompensar com a vida eterna os sofrimentos da vida presente, não a qualificam como algo que deva ser mantido para o homem. Segundo Freud,

\footnotetext{
Nosso Deus, logos, atenderá todos esses desejos que a natureza a nós externa permita, mas fa-lo-á de modo muito gradativo, somente num futuro imprevisível e para uma nova geração de homens. Não promete compensação para nós, que sofremos penosamente com a vida. No caminho para esse objetivo distante, suas doutrinas religiosas terão de ser postas de lado, por mais que as primeiras tentativas falhem ou os primeiros substitutos se mostrem insustentáveis. Você sabe por que: a longo prazo, nada pode resistir à razão e à experiência, e a contradição que a religião oferece a ambas é palpável demais. Mesmo as ideias religiosas purificadas não podem escapar a esse destino, enquanto tentarem preservar algo da consolação da religião. Indubitavelmente, se confinarem à crença num ser espiritual superior, cujas qualidades sejam indefiníveis e cujos intuitos não possam ser discernidos, não só estarão à prova do desafio da ciência, como também perderão sua influência sobre o interesse humano. (FREUD, 1927/1976, p. 68).
}

Ele deixa bem claro que a religião tem como destino ser superada à medida que o homem se torna um ser científico, e nem mesmo as consolações advindas do discurso religioso serão suficientes para impedir tal fim. Algo interessante a se notar é que Freud substitui o deus da crença religiosa pela crença no deus logos. E se esse Deus não passasse de uma ilusão, tal fato não traria tantos prejuízos ao homem, o que não acontece com o deus da crença religiosa.

Freud posteriormente reconhece a sua análise como extremamente negativa em $O$ futuro de uma ilusão e afirma que, na perspectiva psicanalítica, é possível dar à religião certo 
aspecto de verdade, que não seria material, mas sim histórico. Essa posição já está posta em seu livro Totem e tabu de 1913, a partir da reconstrução do mito da morte do pai primitivo, exposto no capítulo IV da referida obra.

Nas palavras de Freud,

lemos que em 'O Futuro de uma Ilusão' exprimi uma avaliação essencialmente negativa da religião. Depois, encontrei uma fórmula que lhe fazia melhor justiça: embora admitindo que sua força reside na verdade que ela contém, mostrei que a verdade não era uma verdade material mas histórica. (FREUD 1933/1976, p. 90).

A verdade histórica da religião coloca-se para Freud como um novo problema a ser investigado e por isso o vienense procurará elucidá-la. O discurso adotado agora não é mais o cientificista, mas sim o psicanalítico. Nesse estudo psicanalítico da religião, Freud não ultrapassará os limites do psiquismo humano. Desse modo, a experiência religiosa constituirse-á basicamente como uma experiência psicológica, não levando em conta a dimensão transcendente do homem, mas apenas as estruturas do corpo e do psiquismo.

Analisada do ponto de vista psicanalítico, a religião também não passará de uma ilusão, mas agora embasada na relação entre pai e filho, em que este sente a necessidade da proteção paterna, mas ao mesmo tempo o odeia por separá-lo de sua mãe, com a qual mantinha uma relação fusional quando bebê. Esse sentimento infantil, para Freud, perdura por toda a idade adulta e é nele que se funda a ideia de Deus. Este último nada mais é que a imagem idealizada do pai, na qual a criança, e agora o adulto, busca proteção para superar o seu desamparo. Essa criação de um pai onipotente e protetor é fruto da imaginação da criança. A fixação a essa imagem, na idade adulta, constitui, para Freud, uma ilusão. Isso não faz dessa fixação um erro ou um engano, mas sim uma produção psíquica fundada no desejo. É a força desse desejo que motiva a produção da ilusão e alimenta a crença em Deus. Segundo Freud,

\footnotetext{
A psicanálise tornou conhecida a íntima conexão existente entre o complexo do pai e a crença em Deus. Fez ver que um Deus pessoal nada mais é, psicologicamente, do que uma exaltação do pai, e diariamente podemos observar jovens que abandonam suas crenças religiosas logo que a autoridade paterna se desmorona. (FREUD, 1910/1976, p. 112).
}

Como se pode ver, o discurso freudiano sobre a religião caracteriza-se pela adesão a duas vias de análise. Por um lado, tem-se o viés científico e por outro, o viés psicanalítico. Ambos chegam à conclusão de que a religião é uma ilusão humana que deve ser superada, pois ela nada mais é que a tentativa dos indivíduos de lidar com o desamparo. Deus nada mais é que a figura do pai idealizado. Nesse sentido, o caminho para sair da ilusão religiosa é a 
ciência, que fará com que o homem caminhe em direção ao seu apogeu enquanto ser humano e consiga se livrar das ilusões da infância.

\section{CONSIDERAÇÕES FINAIS}

Este artigo procurou mostrar o contexto da concepção alvesiana de religião a partir das ideias de Feuerbach, Marx, Nietzsche e Freud. Nota-se que a religião nestes autores é tratada como algo que depende da imaginação em sua face enganadora e, portanto, o que deve ser superado, algo cuja função social não passaria de mera querela, mais atrapalhando do que ajudando o homem. No entanto, será que esta seria a única visão possível sobre a religião? Será que para além da suposta ilusão, da mentira, do engodo não haveria alguma função positiva para a imaginação e para a religião nesse mundo? Algo parece faltar ao se analisar esses filósofos, e é essa deficiência que Rubem Alves e vários outros filósofos e teólogos pretenderão superar a partir do século XX.

\section{REFERÊNCIAS}

ALVES, Rubem. O enigma da religião. 6 ed. Campinas: Papirus, 2007.

DRAWIN, Carlos Roberto. Paradoxo da finitude: sobre o sentido onto-antropológico da psicanálise freudiana. p. 34-39. Tese [doutorado]. Disponível em http://www.bibliotecadigital.ufmg.br/dspace/handle/1843/BUBD-89KNXD. Acesso em: 06 jan. 2017.

FEUERBACH, Ludwig. Preleções sobre a essência da religião. 2 ed. Campinas: Papirus, 1989.

FEUERBACH, Ludwig. (IV, 224) conforme a edição Suhrkamp. In: SOUZA, Draiton Gonzaga de. $O$ ateísmo antropológico de Ludwig Feuerbach. 2 ed. Porto Alegre: EDIPUCRS, 1994.

FEUERBACH, Ludwig. A essência do cristianismo. 2 ed. Lisboa: Fundação Calouste Gulbenkian, 2002.

FEUERBACH, Ludwig. Preleções sobre a essência da religião. In: SOUZA, Draiton Gonzaga de. O ateísmo antropológico de Ludwig Feuerbach. 2 ed. Porto Alegre: EDIPUCRS, 1994.

FREUD, Sigmund. Atos obsessivos e práticas religiosas. Rio de Janeiro: IMAGO, 1976. (Obras Psicológicas Completas de Sigmund Freud; 9) Original publicado em 1907.

FREUD, Sigmund. O futuro de uma ilusão. Rio de Janeiro: IMAGO, 1976. (Obras Psicológicas Completas de Sigmund Freud; 21). Original publicado em 1927. 
FREUD, Sigmund. Leonardo da Vinci e uma lembrança da sua infância. Rio de Janeiro: IMAGO, 1976. (Obras Psicológicas Completas de Sigmund Freud; 11). Original publicado em 1910.

FREUD, Sigmund. Um estudo autobiográfico. Rio de Janeiro: IMAGO, 1976. (Obras Psicológicas Completas de Sigmund Freud; 20). Original publicado em 1933.

KAUFMANN, Walter. Philosophy, psycologist, antichrist 4 th. Princenton: Pinceton University Press, 1974. 532 p.

MARX, Karl; ENGELS, Friedrich. Introdução à crítica da filosofia do direito de Hegel. Tradução Artur Morão. Covilhã: Lusosofia Press, 2008.

NIETZSCHE Friedrich. A gaia ciência. São Paulo: Martin Claret, 2004.

NIETZSCHE, Friedrich. Assim falou Zaratustra. São Paulo: Martin Claret, 2004.

NIETZSCHE, Friedrich. O anticristo: maldição ao cristianismo. São Paulo: Companhia das Letras, 2007.

ROCHA, Zeferino de Jesus Barbosa; MACIEL, Karla Daniele de Sá Araujo. Dois discursos de Freud sobre a religião. Revista Mal-estar e subjetividade, Fortaleza, v. 8, n. 3, p. 729-754, set. 2008 .

ZILLES, Urbano. Filosofia da religião. 2 ed. São Paulo: Paulus, 1991. 